\title{
The Effect of Organisational Ethical Culture on Organisational Citizenship Behaviour of Information Technology Organisations in Egypt
}

\author{
Christine Karmy Gad El Karim Srour ${ }^{1}$, Amr Kheir-El-Din ${ }^{2}$ and Yasmine M. Samir ${ }^{3}$ \\ ${ }^{1,2 \& 3}$ Faculty of Commerce, Ain Shams University, Cairo, Egypt.
}

CITATION: Srour, Christine Karmy Gad El Karim, Kheir-El-Din, Amr and Samir, Yasmine M. (2020), "The Effect of Organisational Ethical Culture on Organisational Citizenship Behaviour of Information Technology Organisations in Egypt", MERC Global's International Journal of Management, Vol. 8, Issue 4, pp. 145-157.

ARTICLE HISTORY: Submitted: April 27, 2020, Revision received: June 05, 2020, Accepted: June 27,2020

\section{ARTICLE TYPE: Research paper}

\begin{abstract}
The purpose of this study is to investigate the effect of organisational ethical culture on organisational citizenship behaviour of information technology employees in Egypt. The research adopted a modern organisational citizenship behaviour construct to avoid outdated, unnecessary dimensions in older constructs. The research used a quantitative approach to collect the data from four information technology organisations in Cairo and Giza. The data were analysed using Spearman's rank correlation coefficient and Multiple Linear Regression Analysis. The results show that organisational ethical culture had a significant positive effect on employees' organisational citizenship behaviour. Nevertheless, a few sub-variables had insignificant effects like; Clarity's insignificant effect on employees' voice behaviour, Feasibility's insignificant effect on employees helping behaviour, Transparency's insignificant effect on employees' sustainability, and sanctionability's insignificant effect on employees' social participation. These results indicate that managers should encourage transparent resource allocation and encourage informal relationships. More recommendations are presented in this paper that can help organisations benefit from the desirable and numerous consequences of organisational citizenship behaviour and organisational ethical culture.
\end{abstract}

KEYWORDS: Information technology organisations, Organisational ethical culture, Organisational citizenship behaviour.

\section{REFERENCES}

1. Appelbaum, S. H.; St-Pierre, N. and Glavas, W. (1998), "Strategic organisational change: the role of leadership, learning, motivation and productivity", Management Decision, Vol. 36, Issue 5, pp. 289-301.

2. Baker, T. L.; Hunt, T. G. and Andrews, M. C. (2006), "Promoting ethical behaviour and organisational citizenship behaviours: The influence of corporate ethical values", Journal of Business Research, Vol. 59, Issue 7, pp. 849-857.

3. Barnett, T. and Vaicys, C. (2000), "The Moderating Effect of Individuals' Perceptions of Ethical Work Climate on Ethical Judgments and Behavioural Intentions", Journal of Business Ethics, Vol. 27, pp. 351362

4. Colaco, B. and Loi, N. M. (2019), "Investigating the relationship between perception of an organisation's ethical culture and worker motivation”, International Journal of Organisational Analysis, Vol. 27, Issue 5, pp. 1392-1408.

5. DeBode, J. D.; Armenakis, A. A.; Feild, H. S. and Walker, A. G. (2013), "Assessing Ethical Organisational Culture", The Journal of Applied Behavioural Science, Vol. 49, Issue 4, pp. 460-484.

6. Dekas, K. H.; Bauer, T. N.; Welle, B.; Kurkoski, J. and Sullivan, S. (2013), "Organisational Citizenship Behaviour, Version 2.0: A review and Qualitative Investigation of OCBs for Knowledge Workers at Google and beyond", Academy of Management Perspectives, Vol. 27, Issue 3, pp. 219-237. 
7. Donaldson, S. I. and Grant-Vallone, E. J. (2002), "Understanding Self-Report Bias in Organisational Behaviour Research", Journal of Business and Psychology, Vol. 17, Issue 2, pp. 245-260.

8. Emary, N. E. (2018), "Egypt's IT/ITeS Exports on Track to Achieve Ambitious Growth Targets as Offshoring Industry Embraces 3rd Platform Technologies", available at: https://www.idc.com/getdoc.jsp?containerId=prCEMA43545618, (accessed 1 August, 2018)

9. Fayyaz, Razieh and Azizinia, Maryam (2016), "An investigation into the impact of ethics on reinforcing organisational citizenship behaviour in arts and cultural clubs of the mosques in Esfahan", International Journal of Organisational Leadership, Vol. 5, pp. 208-217.

10. Gao, Y. and He, W. (2017), "Corporate social responsibility and employee organisational citizenship behaviour", Management Decision, Vol. 55, Issue 2, pp. 294-309.

11. Gardner, G. T. and Stern, P. C. (2002), Environmental Problems and Human Behaviour, $2^{\text {nd }}$ Ed., Pearson Custom Publishing, Boston.

12. Graham, J. W. (1995), "Leadership, Moral Development, and Citizenship Behaviour", Business Ethics Quarterly, Vol. 5, Issue 1, pp. 43-54.

13. Grimmelikhuijsen, S. G. and Meijer, A. J. (2012), "Effects of Transparency on the Perceived Trustworthiness of a Government Organisation: Evidence from an Online Experiment", Journal of Public Administration Research and Theory, Vol. 24, Issue 1, pp. 137-157.

14. Harvey, J.; Bolino, M. C. and Kelemen, T. K. (2018), "Organisational Citizenship Behaviour in the 21st Century: How Might Going the Extra Mile Look Different at the Start of the New Millennium?", Research in Personnel and Human Resources Management, pp. 51-110.

15. Howard, J. L.; Johnston, A. C.; Wech, B. A. and Stout, J. (2015), "Aggression and Bullying in the Workplace: It's the Position of the Perpetrator that Influences Employees' Reactions and Sanctioning Ratings.”, Employee Responsibilities and Rights Journal, Vol. 28, Issue 2, pp. 79-100.

16. Huhtala, M.; Feldt, T.; Lämsä, A. M.; Mauno, S. and Kinnunen, U. (2011), "Does the Ethical Culture of Organisations Promote Managers' Occupational Well-Being? Investigating Indirect Links via Ethical Strain”, Journal of Business Ethics, Vol. 101, Issue 2, pp. 231-247.

17. Huhtala, M.; Kaptein, M. and Feldt, T. (2015) "How perceived changes in the ethical culture of organisations influence the wellbeing of managers: A two-year longitudinal study", European Journal of Work and Organisational Psychology, Vol. 25, Issue 3, pp. 335-352.

18. Hunt, S. D.; Wood, V. R. and Chonko, L. B. (1989), "Corporate Ethical Values and Organisational Commitment in Marketing”, Journal of Marketing, Vol. 53, Issue 3, pp. 79.

19. Jondle, D.; Ardichvili, A. and Mitchell, J. (2013), "Modeling Ethical Business Culture: Development of the Ethical Business Culture Survey and Its Use to Validate the CEBC Model of Ethical Business Culture", Journal of Business Ethics, Vol. 119, Issue 1, pp. 29-43.

20. Kalshoven, K.; Hartog, D. N. D. and Hoogh, A. H. D. (2011), "Ethical leadership at work questionnaire (ELW): Development and validation of a multidimensional measure", The Leadership Quarterly, Vol. 22, Issue 1, pp. 51-69.

21. Kaptein, M. (1998), Ethics Management: Auditing and developing the ethical content of organisations, Dordrecht: Springer.

22. Kaptein, M. (2008), "Developing and testing a measure for the ethical culture of organisations: The corporate ethical virtues model”, Journal of Organisational Behaviour, Vol. 29, Issue 7, pp. 923-947.

23. Lin, W.; Koopmann, J. and Wang, M. (2018), "How Does Workplace Helping Behaviour Step Up or Slack Off? Integrating Enrichment-Based and Depletion-Based Perspectives", Journal of Management, Vol. 46, Issue 3, pp. 385-413.

24. Mayer, D. M.; Aquino, K.; Greenbaum, R. L. and Kuenzi, M. (2012), "Who Displays Ethical Leadership, and Why Does It Matter? An Examination of Antecedents and Consequences of Ethical Leadership", Academy of Management Journal, Vol. 55, Issue 1, pp. 151-171.

25. McLean, A. (2011), "Ethical frontiers of ICT and older users: cultural, pragmatic and ethical issues", Ethics and Information Technology, Vol. 13, Issue 4, pp. 313-326.

26. Mitonga-Monga, J. (2019), "Examining Organisational Citizenship Behaviour as an Outcome of an Ethical Work Culture in a Developing Country" Journal of Contemporary Management, Vol. 16, Issue 1, pp. 333-356.

27. Mitonga-Monga, J. and Cilliers, F. (2016), "Perceived Ethical Leadership: Its Moderating Influence on Employees' Organisational Commitment and Organisational Citizenship Behaviours", Journal of Psychology in Africa, Vol. 26, Issue 1, pp. 35-42.

28. Morris, M. W.; Podolny, J. and Sullivan, B. N. (2008), "Culture and Coworker Relations: Interpersonal Patterns in American, Chinese, German, and Spanish Divisions of a Global Retail Bank", Organisation Science, Vol. 19, Issue 4, pp. 517-532.

29. Nakano, C. (2007), "The Significance and Limitations of Corporate Governance from the Perspective of Business Ethics: Towards the Creation of an Ethical Organisational Culture", Asian Business \& Management, Vol. 6, Issue 2, pp.163-178.

30. Ng, T. W. H. and Feldman, D. C. (2011), "Employee voice behaviour: A meta-analytic test of the conservation of resources framework", Journal of Organisational Behaviour, Vol. 33, Issue 2, pp. 216234. 
31. O'Fallon, M. J. and Butterfield, K. D. (2005), “A Review of The Empirical Ethical Decision-Making Literature: 1996-2003”, Journal of Business Ethics, Vol. 59, Issue 4, pp. 375-413.

32. Organ, D. W.; Podsakoff, P. M. and MacKenzie, S. B. (2006), Organisational citizenship behaviour: Its nature, antecedents, and consequences, USA: Sage Publications, Inc.

33. Podsakoff, P. M.; MacKenzie, S. B.; Paine, J. B. and Bachrach, D. G. (2000), “Organisational Citizenship Behaviours: A Critical Review of the Theoretical and Empirical Literature and Suggestions for Future Research", Journal of Management, Vol. 26, Issue 3, pp. 513-563.

34. Qi, Y. and Ming-Xia, L. (2013), "Ethical leadership, organisational identification and employee voice: examining moderated mediation process in the Chinese insurance industry", Asia Pacific Business Review, Vol. 20, Issue 2, pp. 231-248.

35. Richer, S. F.; Blanchard, C. and Vallerand, R. J. (2002), "A Motivational Model of Work Turnover” Journal of Applied Social Psychology, Vol. 32, Issue 10, pp. 2089-2113.

36. Ruiz-Palomino, P. and Martínez-Cañas, R. (2014), "Ethical Culture, Ethical Intent, and Organisational Citizenship Behaviour: The Moderating and Mediating Role of Person-Organisation Fit", Journal of Business Ethics, Vol. 120, Issue 1, pp. 95-108.

37. Sağnak, M. (2017), "Ethical Leadership and Teachers' Voice Behaviour: The Mediating Roles of Ethical Culture and Psychological Safety”, Educational Sciences: Theory \& Practice, Vol. 17, Issue 4, pp. 11011117.

38. Sias, P. M. and Cahill, D. J. (1998), "From coworkers to friends: The development of peer friendships in the workplace", Western Journal of Communication, Vol. 62, Issue 3, pp. 273-299.

39. Tansky, J. W. (1993), "Justice and organisational citizenship behaviour: What is the relationship?", Employee Responsibilities and Rights Journal, Vol. 6, Issue 3, pp. 195-207.

40. Turnipseed, D. L. (2002), "Are good soldiers good? Exploring the link between Organisation Citizenship Behaviour and personal ethics", Journal of Business Research, Vol. 55, Issue 1, pp. 1-15.

41. Valentine, S.; Godkin, L.; Fleischman, G. M. and Kidwell, R. (2011), "Corporate Ethical Values, Group Creativity, Job Satisfaction and Turnover Intention: The Impact of Work Context on Work Response", Journal of Business Ethics, Vol. 98, Issue 3, pp. 353-372.

42. VanSandt, C. V. and Neck, C. (2003), "Bridging Ethics and Self Leadership: Overcoming Ethical Discrepancies between Employee and Organisational Standards", Journal of Business Ethics, Vol. 43, Issue 4, pp. 363387.

43. Vogelgesang, G. R. and Lester, P. B. (2009), "How Leaders Can Get Results by Laying it on the Line", Organisational Dynamics, Vol. 38, Issue 4, pp. 252-260.

44. Walumbwa, F. O.; Wang, P.; Wang, H.; Schaubroeck, J. and Avolio, B. J. (2010), "Psychological processes linking authentic leadership to follower behaviours", The Leadership Quarterly, Vol. 21, Issue 5, pp. 901-914.

45. Westerman, C. Y. K.; Park, H. S. and Lee, H.-E. (2015), "Cultural Differences in the Effects of Inequity on Coworker Friendships", Human Communication. A Publication of the Pacific and Asian Communication Association, Vol. 10, Issue 2, pp. 82-102.

46. Yen, H. R.; Li, E. Y. and Niehoff, B. P. (2008), "Do Organisational Citizenship Behaviours lead to Information System success?”, Information \& Management, Vol. 45, Issue 6, pp. 394-402. 